\title{
SLOVENIAN COAST SEA FLOODS RISK
}

\section{OGROŽENOST SLOVENSKE OBALE ZARADI MORSKIH POPLAV}

Nataša Kolega

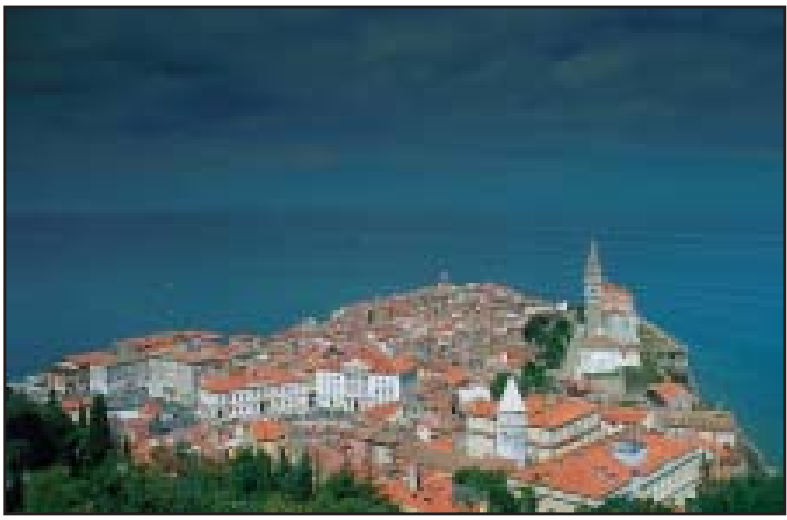

Standing on a flysch ridge Piran is relatively safe from sea floods with the exception of its lower-central part (photograph: Matevž Lenarčič). Z izjemo osrednjega dela mesta je Piran zaradi lege na flišnem hrbtu sorazmerno varen pred poplavami morja (fotografija: Matevž Lenarčič)

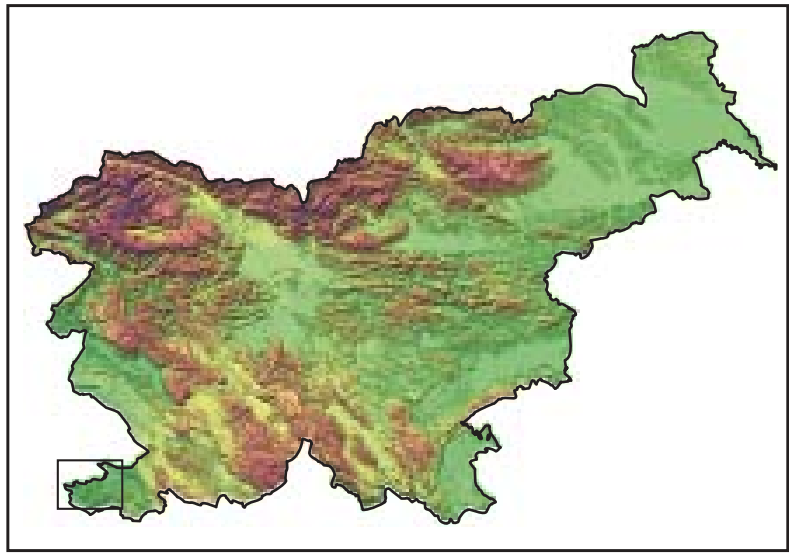




\section{Slovenian coast sea floods risk}

UDC: 556.166(497.4-14)

COBISS: 1.01

ABSTRACT: Article gives a review of sea floods on Slovenian coast with emphasis on their formation, extent and consequences. Sea floods are occurring every year, but they vary in frequency and extent. Consequently, the damage caused by floods also varies. Sea floods rise with flood tides, strong south winds and drops in air pressure. They are more frequent in autumn and winter, but they occur in spring too. The article presents a complete review of sea floods from the beginning of measurements in Koper to present-day, an analysis of flooded regions and influence of climate changes on sea floods.

KEY WORDS: sea, sea floods, flooded regions, hazard, coast, Slovenia.

The article was submitted for publication on March 24, 2006.

ADDRESS:

Nataša Kolega, B. Sc.

Harpha sea, d. o. o.

Čevljarska ulica 8, SI - 6000 Koper

E-mail:natasa@harphasea.si

\section{Contents}

1 Introduction $\quad 145$

2 Methods 145

3 Causes of floods $\quad 145$

$\begin{array}{ll}3.1 & \text { Flood tides development impact factors } \\ 3.146\end{array}$

$\begin{array}{ll}3.1 .1 & 146 \\ 3.12 & \text { Wind and waves }\end{array}$

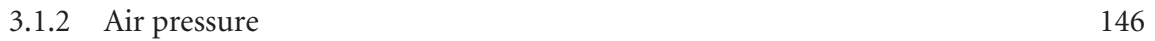

$\begin{array}{ll}\text { 3.1.3 Weather fronts } & 146\end{array}$

$\begin{array}{ll}3.1 .4 & \text { Coast shape } \\ 3.2 & 146\end{array}$

$\begin{array}{lll}3.2 & \text { Sea level values during sea floods } & 147\end{array}$

$4 \quad$ Some data about floods between years 1963 and $2003 \quad 147$

4.1 Flood and storm between $3^{\text {rd }}$ and $5^{\text {th }}$ November, 1966

4.2 Floods between $25^{\text {th }}$ and $26^{\text {th }}$ November $1969 \quad 147$

4.3 Floods in years 1979, 1980 and $1982 \quad 148$

$5 \quad$ Statistical analysis of sea flood data between years 1963 and $2003 \quad 148$

6 Mapping of flood areas on the Slovenian coast 149

6.1 The surface of flood areas during extreme and yearly floods 149

$\begin{array}{ll}6.2 \text { Description of flood areas } & 150\end{array}$

$\begin{array}{ll}\text { 6.2.1 Ankaran } & 150\end{array}$

$\begin{array}{lll}6.2 .2 & \text { Koper } & 153\end{array}$

$\begin{array}{lll}6.2 .3 & \text { Izola } & 153\end{array}$

$\begin{array}{ll}\text { 6.2.4 Strunjan and Fiesa } & 153\end{array}$

$\begin{array}{lll}6.2 .5 & \text { Piran } & 153\end{array}$

$\begin{array}{lll}\text { 6.2.6 Portorož } & 154\end{array}$

$\begin{array}{lll}\text { 6.2.7 Lucija } & 154\end{array}$

$\begin{array}{ll}\text { 6.2.8 Seča and Sečovlje } & 154\end{array}$

$\begin{array}{lll}6.3 & \text { Number of residents in exposed areas } & 154\end{array}$

$\begin{array}{ll}\text { 6.4 Building plans in flooding areas } & 155\end{array}$

$\begin{array}{ll}\text { 6.5 Influence of global warming on sea flooding } & 155\end{array}$

6.5.1 Analysis of map of flooding area, on eventual rise of sea level by $50 \mathrm{~cm}$,
because of global worming

7 Conclusion 156

8 References 157 


\section{Introduction}

Sea floods are often on Slovenian coast. Their extent and inflicted damage are usually not large, but they pose a significant financial cost on some occasions.

Sea floods happen because of flood tides, which are caused by some meteorological factors in combination with hydrological factors. There is a marked influence of strong south winds and drops in air pressure. Sea floods are most frequent in autumn and rather rare in spring.

Systematic tide measurements begun in 1958, but the data are available only since 1963. They give us the opportunity for detailed analysis of sea floods and inflicted damage with the support of statistical methods. Using above mentioned data, observation and mapping methods, we made two maps of flooded regions.

\section{Methods}

The main theoretical method used was a review of literature, consisting of articles about individual floods in the past, and records from measurements of a mareograph at a custom pier in Koper between 1963 and 2003. We used verbal sources (accounts by tenants of flooded areas) as well.

Mapping of the flooded areas was made by analyzing less accurate older maps of flooded areas, a digital relief model and verbal sources of people remembering the extent of particular floods in the past.

Map of flooded area on Slovenian coast at extreme and yearly floods is based on digital aero photo "snaps«. Flooding areas where then determined by digitizin polygons, using the 25 by 25 metres digital relief model of Slovenia, for regions that are $0.0 \mathrm{~m}, 1.0 \mathrm{~m}$ and $2.0 \mathrm{~m}$ above sea level. These polygons were then overlaid on digital aerial photos. With that, we formed closed areas of stated heights above sea levels. Since the digital relief model is based on grid of 25 meters, we could not determine narrow coast areas, where the height changes substantially in an area of 25 by 25 meters. An example of such area is Piran, where the height quickly changes from a plane to the top of flysch cliff. That is why flood areas were determined by observations and interviewing people who have experienced floods. With the use of digital relief model, there is one another impediment: the values of height above sea are integer numbers (in meters) only, so one can not determine areas with height of $30 \mathrm{~cm}$ above sea level.

The map of flooded area if the sea level rises by $50 \mathrm{~cm}$ is based on digital relief model to give it more plastic illustration. Map scale is smaller than the one used in map of flooded area for present sea levels, because these are only predictions. Map shows the flooded areas at $50 \mathrm{~cm}$ sea level rise. The rise of sea level for $50 \mathrm{~cm}$ is a prediction of sea rise due to global warming for $21^{\text {st }}$ century. The amp was calculated using maps of flooded area at extreme and yearly floods and digital relief model.

\section{Causes of floods}

Main cause of sea floods on Slovenian coast are flood tides; however, there are other factors which determine height of tides, such as wind, undulation, air pressure, Moon gravity and tide type, weather fronts and coast shape. Tide height and timing of the flood tides can be accurately anticipated and so it is possible to anticipate floods too.

Tides are alternating rising and decreasing of sea level, caused by moon and sun gravity (Kunaver in ostali 1996). It propagates as a long wave, causing periodic changes in sea level. Its rising is denominated as high tide and its decreasing as low tide. They alternate in approximately 6 to 6 and a half hours.

When moon rotates around Earth, it literally changes the shape of the planet. When moon crosses the local meridian (this moment is denominated as moon upper culmination), it attracts masses of water and the sea level rises. At the same time, on the other side of the earth, we have the same event, with lower amplitude; it is denominated moon lower culmination. When moon rises or sets, we have low tide. That is at 90 degrees east and west from longitude where the tide is high and the moon is attracting the sea.

Tides are also affected by sun which is very far from earth, but represents a notable factor because of its great mass. Its influence is less than one half of that of the moons. 
Tide amplitude is highest at new and full moon, when the sun and moon are in conjunction or opposition (sun, moon and earth are aligned) and their influences adds up. The tide on this position is denominated spring tide. The tides are weakest at waxing and waning moon, when earth - moon direction forms a right angle with earth - sun direction, because their influence subtracts. This is period of neap tide (Robič in Vrhovec 2002).

Tide amplitude greatly differs around the world, from some centimeters to over 20 meters. Average daily amplitude in Koper is around 60 centimeters and can increase greatly with influence of other factors. Maximal difference between high and low tide in Koper was 286 centimeters in th period 1955-1997 (Robič in Vrhovec 2002).

\subsection{Flood tides development impact factors}

\subsubsection{Wind and waves}

The rise and fall of sea level depend on the direction and strength of the wind. The winds from the north cause drops in sea level along Slovenian coast, because they push the water from the north Adriatic to the south. A strong north-east wind is called bora. On the other hand, the winds from the south cause a rise of sea level. Such constant wind blowing from south-east without gusts is called jugo. It usually indicates imminent worsening of the weather. Blowing from the south Adriatic to the north, it pushes the water towards Bay of Trieste. It can also cause high waves. "... The rise of the sea level because of moderate and long-lasting south-east wind can amount to around $25 \mathrm{~cm}$, but the sea level can arise also over half of meter during very strong south-east wind, especially in the autumn and the first half of the winter... (Bernot 1983, 50). The sea often floods the lower parts of the coast during high tides.

The waves are also a consequence of the wind and they have very important role on sea floods. The waves of the south-east wind jugo can reach the height of few meters giving the flood a destructive force. The structures along the coast are often destroyed or damaged during the floods that are accompanied by storm with strong south-east wind and high waves.

\subsubsection{Air pressure}

Air pressure is the second atmospheric factor which affects rising of the sea level. It is actually related to the winds, but changing of air pressure itself also causes changes in sea level. The decrease of air pressure by $1 \mathrm{mb}$ corresponds to the rising of sea level by $1 \mathrm{~cm}$ (Bernot 1993a) or even $1.5 \mathrm{~cm}$ (Robič 2004). The process also works in the opposite direction.

The air pressure can drop by more than $20 \mathrm{mb}$ per day during bad weather and south-east wind. This causes the rise of sea level by $20 \mathrm{~cm}$. At the time when the sea is flooding, air pressure often reaches the values around $992 \mathrm{mb}$ (for example in October 1982), what is much less than long time October average for Koper, which is $117.7 \mathrm{mb}$ (Bernot 1983).

\subsubsection{Weather fronts}

Fronts are related to tides indirectly through air pressure and wind. Typical weather situation for days when the sea is flooding is the following: there is an area of extensive anticyclone above eastern or northern Europe, while a cyclone is situated above Great Britain determining the weather in western Europe. The anticyclone above eastern Europe weakens and slowly moves towards the east while the cyclone above Great Britain deepens and moves towards central Europe. In the end the secondary core of a cyclone is formed south of the Alps in Genova Bay, which is moving towards east and reaches the Slovenian coast. This causes strong south-east winds in the Adriatic sea (Bernot 1983; 1993a; 1993b).

\subsubsection{Coast shape}

Slovenian coast is a ria coast, a characteristic of which is that the major direction of the coast is perpendicular to geological structure. Also characteristic are long bays in sunken river valleys, between which long peninsulas extend far into the sea. Main coast shapes are costal plains in interior of the bays and steep cliffs on the peninsulas. 
Oscillation of the sea level is also affected by a resonant oscillation of the Adriatic sea, which appears in closed or half closed bays. The period of this oscillation is 21 hours (Robič 2004).

In connection with coast shape, one should consider another factor, which by itself does not cause the rise of sea level; however, their effects unite and cause highest floods with grater flood area. Rising of the sea level and pushing the water from the entire Adriatic towards upper Adriatic blocks the mouths of the rivers in this area. The riverine water can not flow out normally and the rivers begin to flood the areas near the mouth of the river - the flood areas of the sea and the rivers join.

\subsection{Sea level values during sea floods}

There are two ways to describe sea level. We can specify how much above or below the long term mean value is the current sea level. The mean value is then 0 , high tides correspond to positive values $(+)$ and low tides to negative values $(-)$.

Alternatively, we can specify the sea level relative to mareographic zero (0) on mareographic station in Koper. In this mode, all values are positive, because the value corresponding to the mean sea level values is $215 \mathrm{~cm}$.

The sea on Slovenian coast floods lowest parts of the coast when the sea level reaches $85 \mathrm{~cm}$ above the mean value or $300 \mathrm{~cm}$ above mareographic zero (Robič and Vrhovec 2002).

The mean value of high tides between years 1958 and 1990 was $248 \mathrm{~cm}$ relative to mareographic zero, or $33 \mathrm{~cm}$ above long term mean value. The mean values for low tide in the same time period was $182 \mathrm{~cm}$ relative to mareographic zero, or $-33 \mathrm{~cm}$ under long term mean value. The mean amplitude was $66 \mathrm{~cm}$. The highest measured sea level was $394 \mathrm{~cm}$ or $179 \mathrm{~cm}$ above long term mean value, in 1969 (Mareographic station in Koper 1969).

\section{Some data about floods between years 1963 and 2003}

Between 1963 and 2003, when data from mareographic station in Koper is available, some major floods occurred.

\subsection{Flood and storm between $3^{\text {rd }}$ and $5^{\text {th }}$ November, 1966}

Sea level has reached the highest point on the 4 th of November at $8 \mathrm{pm}$ and that was $352 \mathrm{~cm}$ (Mareographic station in Koper 1966). At that point, there was approximately half meter of water on the Tartini square in Piran. Storm and high sea level inflicted a considerable damage, mostly in Piran where there are several buildings directly exposed to the sea. The coast walls in Piran were badly shaken and sapped, heavy damage was inflicted upon the coffee shop Tartini in the building of theater (today's Caffe Teater), the bus station office, restaurant Riviera, baths near entrance to the city, restaurant of Hotel Piran and many private garages. A number of cars were smashed. The road between Piran and Lucija was closed for traffic during the whole day, and much damage was inflicted to other parts of Slovenian coast too (Primorske novice 1996). Wooden piers on the beach of Portorož were destroyed, cabin doors were broken, approximately 50 wagons of very fine sand were swept away from the beach and many small boats were torn away from anchorage (Titl 1983).

\subsection{Floods between $25^{\text {th }}$ and $26^{\text {th }}$ November 1969}

During $25^{\text {th }}$ and $26^{\text {th }}$ of November in 1969 , the sea flooded the entire Slovenian coast. In Koper water was $94 \mathrm{~cm}$ high. Coast road from Koper to Sečovlje was flooded in several places and all sections towards Izola, Portorož and Piran as well. The storm inflicted a great deal of damage to cars parked on Tartini square in Piran, because they were submerged in nearly one meter of sea water. Some of them were even smashed against the walls by gusts of wind. Along with the lower parts of Koper, most of Bonifika and its elementary school was flooded (Titl 1983). This was the largest flood in the period studied, and it inflicted most damage. 


\subsection{Floods in years 1979, 1980 and 1982}

On December 22, 1979, the level of the sea reached $356 \mathrm{~cm}$. The then-named JLA road (today's Fornače and Dante Street) was submerged in up to $60 \mathrm{~cm}$ of water. In Piran, Tartini Square and its surroundings were flooded too. The sea passed over the protection bags placed near the crossroads beside Slavnik in Koper and flooded Bonifika. It flooded offices of Splošna banka Koper (today's Banka Koper) and the market place too (Primorske novice 1979).

On October 25, 1980, the sea level reached $361 \mathrm{~cm}$ which is the second highest value in the studied period. Most salt water was again on former JLA road (today's Fornače) in Piran, on Ukmar square in Koper and on Semedelska road. Many cars where flooded on the parking lot of the Triglav hotel in Koper. Damage was limited because the flood was not accompanied by strong southeast wind (Primorske novice 1980).

The sea once more reached a height of $361 \mathrm{~cm}$ on December 6 and 7, 1982. Most affected was Piran and area between Piran and the salt-pans of Sečovlje. Dikes in salt-pans were demolished and the salt-pans were devastated. Much damage was inflicted to plant Začimba of the Droga factory in Seča too. In Izola and Koper, the damage was limited to flooded cars (Titl 1983).

\section{Statistical analysis of sea flood data between years 1963 and 2003}

In this forty-one year period, the sea level has reached the flooding point of $300 \mathrm{~cm}$ or more for 299 times. The mean sea level during floods was $309 \mathrm{~cm}$. The highest measured sea level in studied period was $394 \mathrm{~cm}$, which is an extreme, because such high levels were not usual. On average, there were 7.3 floods per year.

The annual number of floods varies from year to year and so do the highest reached sea levels. The two phenomena are not closely related, because there are years with a small number of floods and low sea levels, as well as years with small number of floods but high sea levels reached. In a similar way, we can not expect high sea levels just because of a large number of floods during that year.

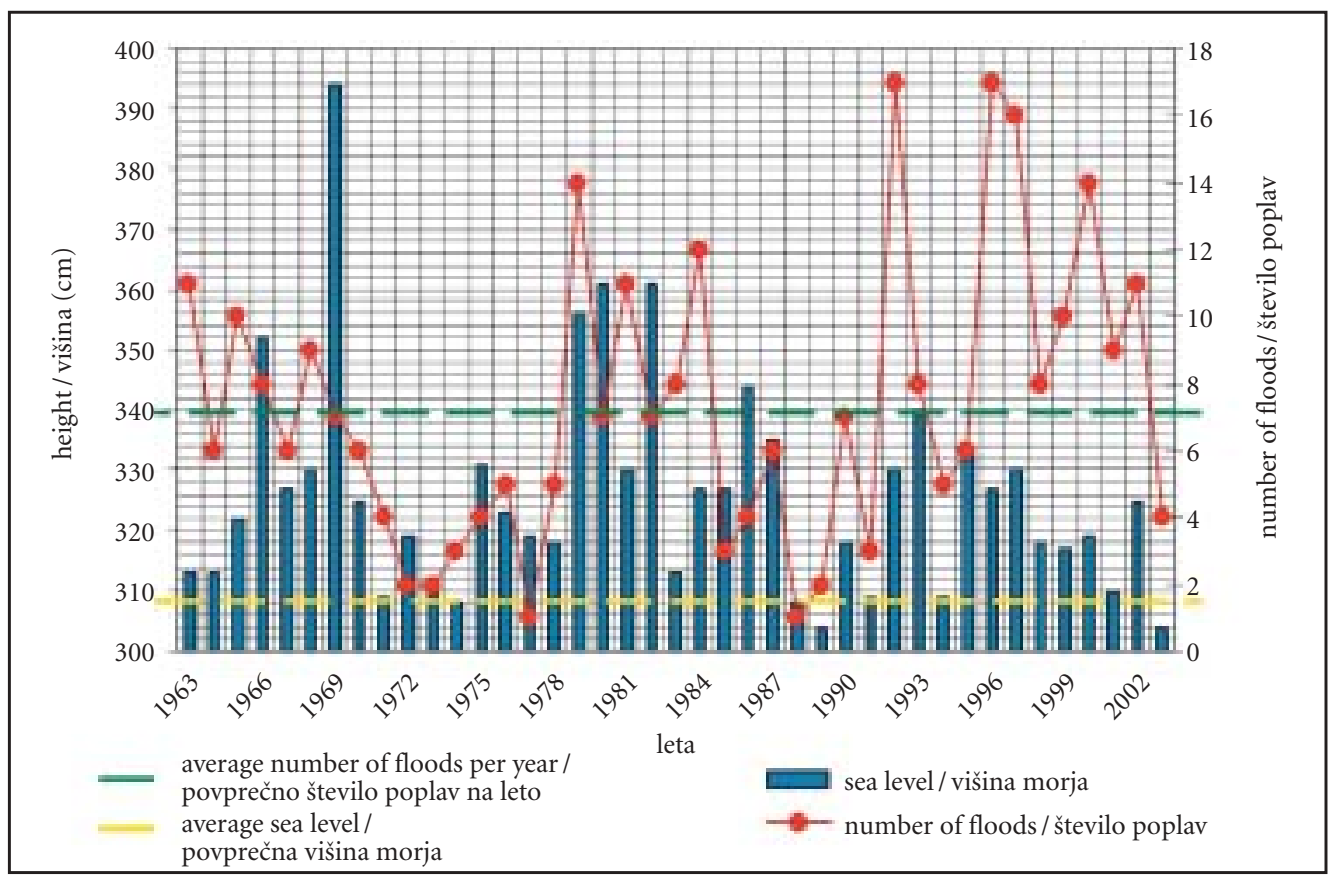

Figure 1: The highest sea levels and the number of floods per year between 1963 and 2003. 


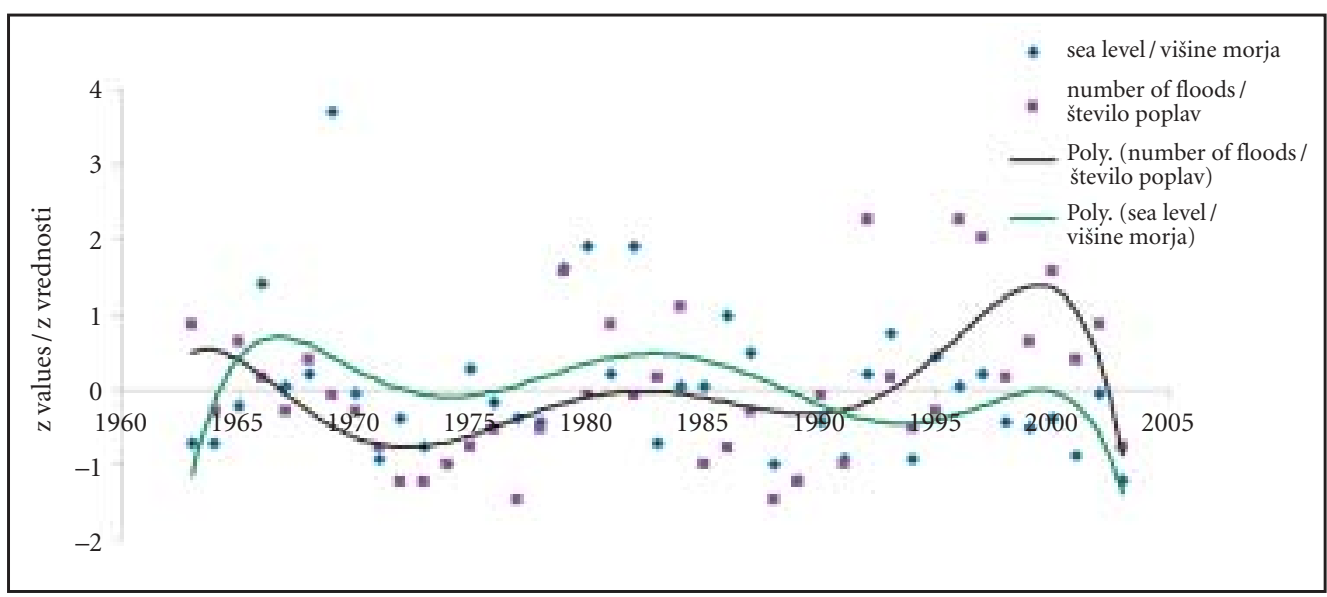

Figure 2: »Z values« of highest sea levels \& »Z values « of number of floods per year.

If we observe only the reached levels during the floods, we can notice a visible trend (Figure 1). For few years, levels are relatively high, followed by a few years with relatively low levels. The series than repeats. From figure 1 it is possible to see three such periods with high levels reached and between them, two periods with lower levels. The number of floods during a year follows a similar cycle.

In the last decade, an increase in the number of floods during the year is visible; however, these floods do not reach high levels.

We calculated Pearson's correlation from the data on number of floods per year and the highest sea levels per year. Obtained correlation is low, 0.247 , which means that the accounted variance is 0.061 , or that we can explain only approximately $6 \%$ of the highest sea levels with the number of floods per year. This is the consequence of the fact that with the Pearson correlation we can calculate only linear correlations. If we interpolate the $" z$ values " with a $6^{\text {th }}$ order polynomial, we can see that the phenomena are correlated. We see (Figure 2) that the curves are correlated. To confirm that, we correlated signs of its derivative, which tells us in how many cases the curves increase or decrease together. We noticed that $90 \%$ of values correlate in common increasing or decreasing. We can assume that the relation between phenomena exists, but we can not prove it with Pearson's correlation, because it presumes linear correlation, which is here obviously not the case.

Then we tried to extrapolate the data from which we eliminated the edge values, which are excessively deviated (values before 1966 and after 1990). If we calculate Pearson's correlation with only this data, the result is 0,551 . The accounted variance is 0,301 , so about $30 \%$ of highest sea levels can be explained with the number of floods. Because the sample size and statistical significance are very low, this value of explained variance means that we can only suspect the existence of a connection between highest sea levels and number of floods between years 1966 and 1990.

Floods are very characteristic of autumn-winter period, from October to January and they are most frequent in November. Figure 3 represents number of floods per month. The floods are also frequent in spring, but very rare in the summer. The reason for such distribution is particularly in higher frequency of Genova cyclone at that time of the year.

\section{Mapping of flood areas on the Slovenian coast}

\subsection{The surface of flood areas during extreme and yearly floods}

Extreme floods reach or exceed the $394 \mathrm{~cm}$ level, which is the highest level the sea has reached between years 1963 and 2003. For the already mentioned flood that occurred on November 26, 1969, less accurate maps have already been drawn by Julij Titl in 1983 (Titl 1983). These maps were used for a more precise delimitation of flood areas. The value $394 \mathrm{~cm}$ almost exactly corresponds to the value of $2 \mathrm{~m}$ altitude on the digital relief model. Geodetic height 0 thus corresponds to a value of $200 \mathrm{~cm}$ on mareographic station in Koper and is represented as height 


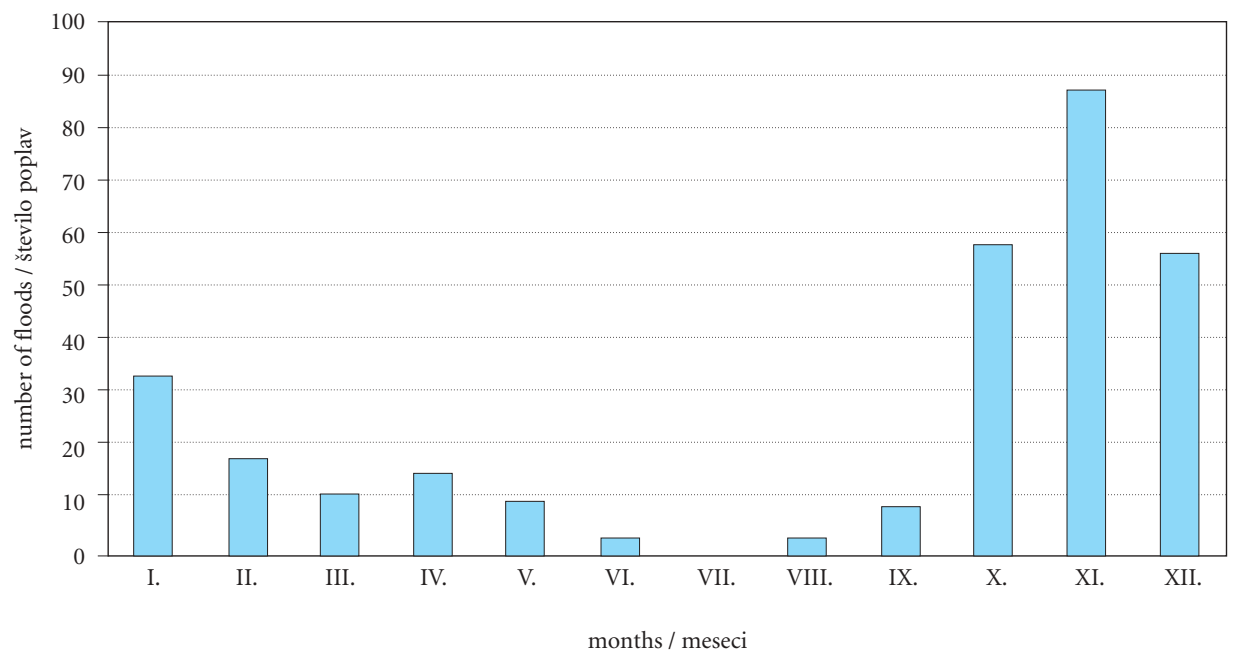

Figure 3: The number of floods per month between years 1963 and 2003.

0 in the digital relief model. Consequently, the value of $1 \mathrm{~m}$ on digital relief model corresponds to $300 \mathrm{~cm}$ and the value of $2 \mathrm{~m}$ corresponds to $400 \mathrm{~cm}$, which is only $6 \mathrm{~cm}$ higher than the highest recorded sea level, $394 \mathrm{~cm}$.

Many people still remember extent of the mentioned flood vividly - especially in Piran, and their recollections were taken into account during the elaboration of map.

The second datum represented on the map is flood area during more frequent, yearly floods at level $330 \mathrm{~cm}$ or $30 \mathrm{~cm}$ above flooding point. For delimitation of corresponding flood area, proper observations of terrain were used, along with multiple observations of floods of this kind of extension in past years.

Flood area is the largest in the municipality of Piran, particularly because of the biggest flood surface - salt-pans of Sečovlje. The smallest flood area is in the municipality of Izola. Flood area of yearly floods represents $26.85 \%$ of flood area during extreme floods.

Table 1: Surface of flood areas during extreme and yearly sea floods.

\begin{tabular}{lc}
\hline Area & Surface in $\mathrm{km}^{2}$ \\
\hline Flood area during extreme floods & \\
\hline Municipality of Koper & 6.12 \\
Municipality of Izola & 0.20 \\
Municipality of Piran & 7.71 \\
All three municipalities together & 14.04 \\
\hline Flood area during yearly floods & \\
\hline Municipality of Koper & 0.25 \\
Municipality of Izola & 0.03 \\
Municipality of Piran & 3.48 \\
All three municipalities together & 3.77 \\
\hline
\end{tabular}

\subsection{Description of flood areas}

\subsubsection{Ankaran}

There are several separated flood areas of different sizes in the Ankaran region. There are flooded areas near the Lazaret border crossing and the gas station near it during extreme floods. Beyond these two buildings no other buildings are threatened. During yearly floods, only a narrow coastal part is flooded. 


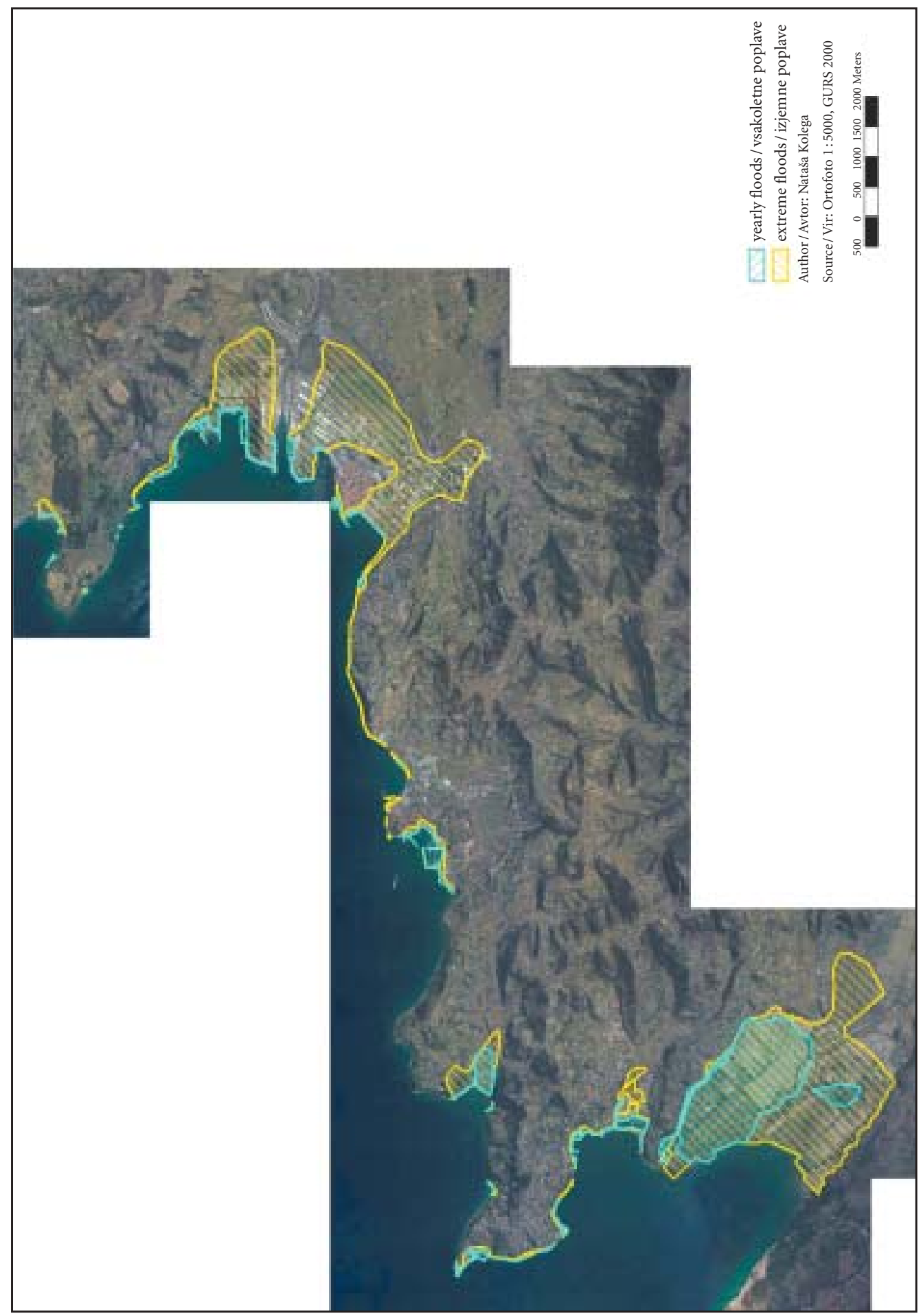

Figure 4: Flood areas on Slovenian coast, during yearly and extreme floods. 


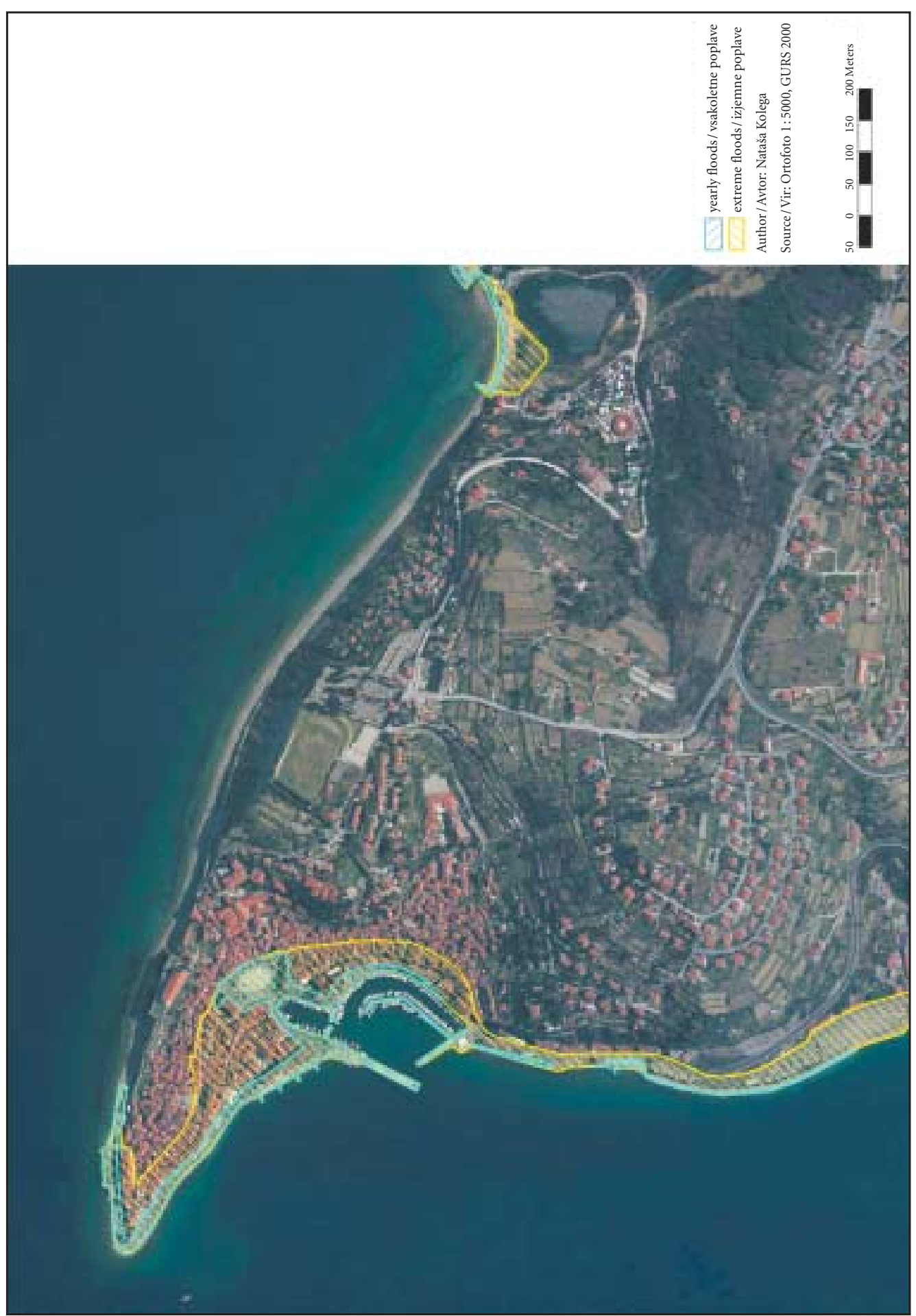

Figure 5: Enlarged section of the above map, representing Piran and its surroundings. 
Approximately $500 \mathrm{~m}$ west of the border crossing, there is a beach with a few buildings, which would be under water during extreme floods. The beach in front of the youth health resort and the so called »Gradis « beach would be flooded as well - but no buildings would be endangered. The next beach to consider is the one in front of the Orthopaedic hospital Valdoltra, where the terrain is lower. The area from here on to the Port of Koper would be under water. In this area, there are a few sections where the extreme floods could cause substantial damage. The autocamp Adria with its buildings is the most problematichalf of it would be flooded during extreme floods. Near Sveta Katarina, during extreme floods, the small port and few nearby buildings would be flooded. Yearly floods in the area of Ankaran do not pose serious threats.

\subsubsection{Koper}

In Koper and its neighborhood, there is a number of areas that would be flooded during extreme floods. Port of Koper would be, because of its location, almost entirely under water. This could cause serious material damage. The water would overflow almost to Srmin. During yearly floods, only the lowest parts of the Port of Koper are flooded, and that doesn't cause serious problems. During extreme floods, the regions flooded would include Bonifika, part of large inhabited areas Olmo and Šalara near the Badaševica river. In the old town of Koper, Marina Koper, Ukmar's square, part of Carpaccio's square, Pristaniška street, Ljubljanska street and Bonifika would be under water during extreme floods. In the old city center, several houses would be under water.

During yearly floods, Semedelska street, part of the marina and the coast area near the harbour would be flooded. Residential buildings are not in danger.

The area towards Žusterna with the parking place and the beach would be under water as well as the main road between Koper and Izola during extreme floods. Only the beach is flooded during yearly floods.

\subsubsection{Izola}

In the area of Izola almost the entire autocamp Jadranka would be flooded during extreme floods. During yearly floods, only its lower coastal part is affected.

The bigger part of shipbuilding yard of Izola would also be flooded during strong and extreme floods, which would likely cause high material damage. The beach west from shipbuilding yard and a small peninsula with the lighthouse would also be flooded.

Large parts of the town Izola itself would also be flooded: near the harbour, Big square, Manizioli's sqare and the entire part to Ljubljanska street and Gorki's street. The water would also cover the marina with its buildings and the area near Simonov zaliv (Simon's Bay), in addition to quite a few residential buildings, especially in old city center.

During yearly floods, only a narrow part of the coast and very few residential buildings would be flooded - mainly those on the Veliki trg (Big Square), and maybe the area near marina.

\subsubsection{Strunjan and Fiesa}

The beach and salt-pans are usualy under water during yearly floods. During extreme events this extends to the area near the stream of Strunjan - the neighborhood of the main crossroads. A few houses in the vicinity would also be affected.

Beside this the sea also overflows the beach in front of the tourist resort Salinera, especially during extreme floods.

In Fiesa, the beach is usually flooded; during extreme floods, the meadow by the lake is under water as well. The buildings are not endangered.

\subsubsection{Piran}

Floods pose the greatest threat to Piran. Also in the past, they have caused the worst damage there. A big part of the old city centre would be flooded during extreme floods. Water would overflow along entire coast around the cape Madona to Ressel's street and the beginning of Gregorčič's street (behind the former Punta hotel) and then to lower part of the Square of $1^{\text {st }}$ May and Verdi's street. The entire Tartini's square and 
the area up to Ulica Svobode and Tomšič's street would be under water. Also flooded would be the Dante's street and entire Fornače. Quite a few houses would be flooded and material damage would be high.

During yearly floods in Piran, the areas under water are Kidrič's and Prešeren's quays, Tartini's square and a part of Cankar's quay with the harbour. Out of the city, only a narrow costal part would be flooded. In contrast to other places, a few houses in Piran are flooded even during yearly floods, especially along Prešeren's and Kidrič's quays.

\subsubsection{Portorož}

In Bernardin, the areas under water, especially during extreme floods, would include the beach in front of Grand hotel Bernardin and the beach and a small harbour near hotel Histrion. Also flooded would be main Bernardin's beach and sailing club Pirat, where a few buildings, including the boathouse of the Faculty for Maritime Studies and Transport would be under water during extreme floods. Additionally, the so called »Students beach « would be flooded during extreme floods and the coast in front of salt storehouses as well.

In Portorož, the beaches would be flooded - the one in front of hotel Riviera and main Portorož's beach. Beside this, the pier and the coast between mentioned beaches would also be flooded.

Buildings in Portorož would not be flooded - not even in case of extreme floods, because they are elevated a little bit.

\subsubsection{Lucija}

In Lucija, quite a large part of the surface would be flooded during extreme floods. Those regions would include the entire marina Portorož and the water would overflow the go-kart track and health centre. Also flooded would be a part of Obala street and Ukmar's street. Along stream Fazan, the water would overflow all the way to Fazan and Fazanska street. In case of extreme floods, many of residential and other buildings would be flooded, causing considerable material damage.

The main Lucija's beach and a narrow part of quay near the canal at the mouth of the Fazan stream which serves as a mooring place for small boats, are flooded during yearly and extreme floods.

The beach and a smaller part of autocamp Lucija would be flooded during extreme floods. The larger part of camping area would not be under water because it is sufficiently elevated.

Yearly floods in Lucija do not cause serious problems because flooded areas are mostly beaches and narrow coastal parts.

\subsubsection{Seča and Sečovlje}

The largest sea flood area on the Slovenian coast is in Seča and Sečovlje. The Sečovlje's salt-pans are in large part flooded even during yearly floods. Tthe salt-pans would be almost entirely under water during extreme flood. The water would overflow also the lower part of the valley blocking the Drnica river. Thus a part of the Sečovlje settlement with cultivable ground in its surroundings would be flooded. Also, a part of the Portorož Airport and few nearby houses would be endangered.

The sea could also cover former Droga's plant Začimba in Saint Jernej in Seča, causing high material damage during extreme floods.

Almost the entire road along the canal of St. Jernej is under water during yearly floods, and in case of extreme floods, water would also cover the small shipbuilding yard and parking lot near the Ribič restaurant. Luckily, the majority of residential buildings in the area are not endangered because of their high elevation.

\subsection{Number of residents in exposed areas}

Many inhabitants live in flooding areas. Yearly floods endanger 22 residents of Piran. In other places, there are no residential buildings which are flooded every year.

All three municipalities together have 87,846 inhabitants. Municipality Koper is 47,539 inhabitants, municipality Izola 14,549 inhabitants and municipality Piran 16,758 of that 4143 are inhabitants of the town of Piran (Census of population 2002). 
In case of extreme floods, 2007 people would be endangered in the three municipalities combined; mostly in municipality of Piran (1262), then municipality of Koper (427) and municipality of Izola (318). About $2.54 \%$ of residents in all three municipalities are in danger, in municipality Piran alone there are $7.53 \%$ of people exposed to floods, while there are $18.75 \%$ of residents exposed to floods in the town itself.

We can conclude that in the case of extreme floods difficult situations may arise because of considerable number of residents. Also supply, traffic, sojourna and other activities would be affected, especially in Piran.

\subsection{Building plans in flooding areas}

In the coastal communities building plans have been approved allowing builidng on flooding areas. In the community of Koper those are the building of a new elementary school, fire brigade house and public heath center in Bonifika, Economic zone Sermin and $3^{\text {rd }}$ pier of the port of Koper.

In the community of Izola, they plan to build the Argolina tourist-business-residential complex and another tourist complex in the vicinity of Simon's bay.

In the community of Piran, plans include widening of the runway of the Portorož Airport, a builiding of a golf course in the vicinity of Sečovlje and an extensive settlement plan for the Seča peninsula, which touches the borders of two major flooding areas - the salt-pans and the tract near canal of Saint Jernej. There are also plans to build a new marina, many villas, hotels and other facilities.

Just a few of the largest plans have been listed; there are many smaller plans, some of them being even more exposed to sea floods.

\subsection{Influence of global warming on sea flooding}

Scientists have been predicting that one of biggest global warming effects would be the rise of sea level. It will rise because of expansion of heated water, melting of glaciers and icebergs around the Earth poles. By comparison with today's sea level, it would rise for about $22 \mathrm{~cm}$ by 2050 and for about $50 \mathrm{~cm}$ by 2100 (Plut 1998).

That is why we prepared a map the flooded areas due to eventual rise of sea level because of global warming. We assumed the $50 \mathrm{~cm}$ rise, which is the prognosis for $21^{\text {st }}$ century.

If the medium sea level will be $0.5 \mathrm{~m}$ higher in the future, then every slightly stronger high tide would cause flooding. If we add $50 \mathrm{~cm}$ to the current average high tide we get the height $298 \mathrm{~cm}$ which is very near the todays flooding point. Taking into account the fact that high tides have an average height of $33 \mathrm{~cm}$, we can conclude that floods would be very frequent - they woulda appear even several times a month. Average flood height, calculated from current values, would be rather high, reaching the level of today's extreme floods $-359 \mathrm{~cm}$. In the case of extreme floods, the sea would submerge the lowest parts of the coast by about $1.5 \mathrm{~m}(444 \mathrm{~cm})$.

Table 2: Calculation of sea heights for predicted rise of $50 \mathrm{~cm}$.

\begin{tabular}{lcc}
\hline & Height of sea level today, in cm & Height of sea level if the level rises for $50 \mathrm{~cm}$, in cm \\
\hline Average sea level & 215 & 265 \\
Flooding point & 300 & 300 \\
Average high tide 1963-2003 & 248 & 298 \\
Average low tide 1963-2003 & 182 & 232 \\
Extreme sea level 1963-2003 & 394 & 444 \\
Average flood 1963-2003 & 309 & 359 \\
Yearly flood 1963-2003 & 330 & 380 \\
\hline
\end{tabular}

\subsubsection{Analysis of map of flooding area, on eventual rise of sea level by $50 \mathrm{~cm}$, because of global worming}

The territory flooded by yearly floods in the case of $50 \mathrm{~cm}$ sea level rise is comparable to the territory flooded today by extreme floods. It occupies about $14 \mathrm{~km}^{2}$, which is about $3 \%$ of the total area of all three coastal municipalities. However in the case of sea level rise for $50 \mathrm{~cm}$, the flooded areas would probably 


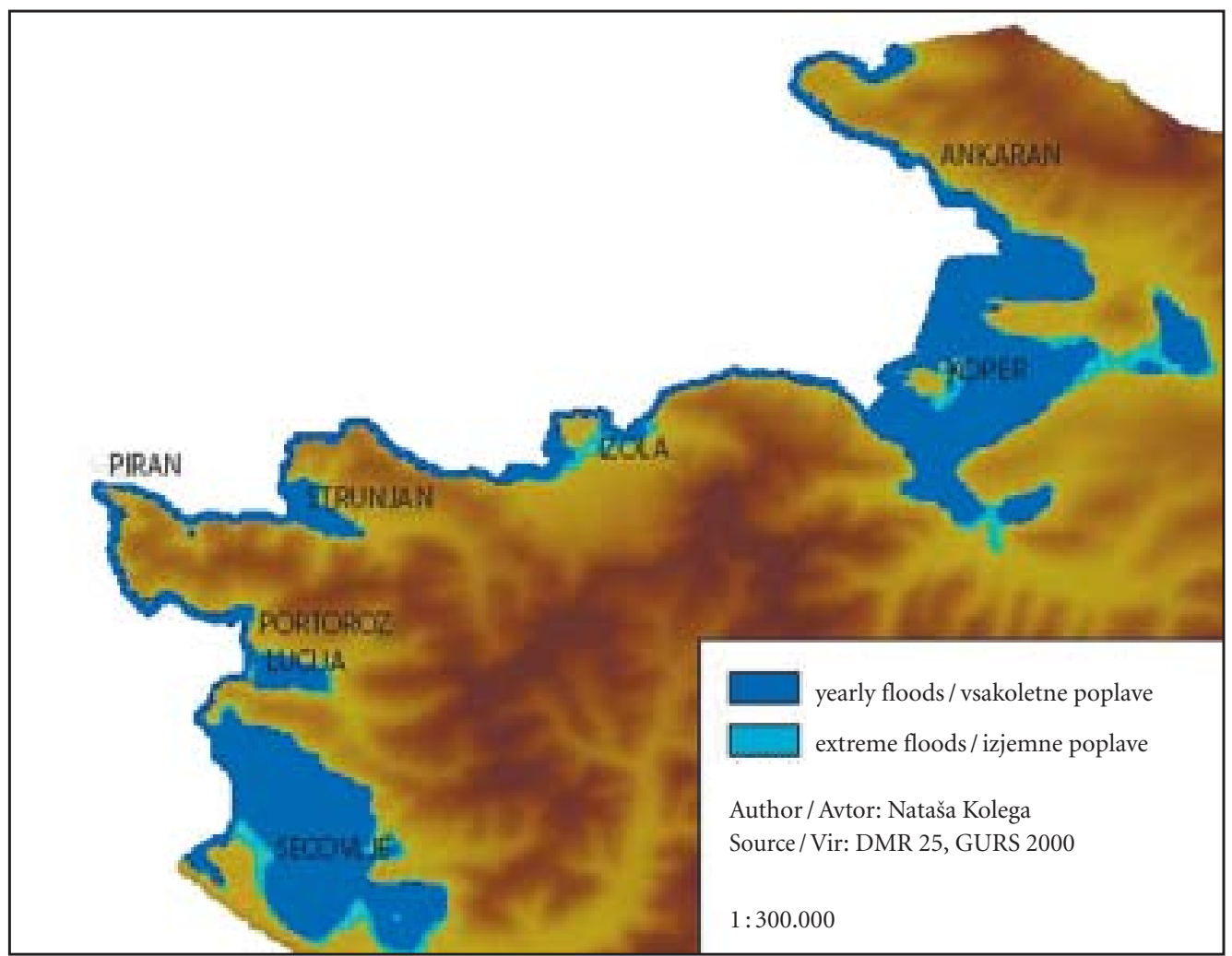

Figure 6: Map of flooding area, on eventual rise of sea level by $50 \mathrm{~cm}$, because of global warming.

be somewhat less extensive, because the sea level would be about $14 \mathrm{~cm}$ lower than current extreme floods (table 2). Same comparison could be made about the number of endangered people. We can deduce that yearly floods, in the case of $50 \mathrm{~cm}$ rise of sea level, would endanger over 1000 people.

The biggest flooded areas would be in the region of Koper's and Ankaran's Bonifika. The Port of Koper would have big difficulties in performing its activities. Flooded areas would be significantly larger in Izola too. They would be somewhat larger in Strunjan and Piran also. The flooded areas would dramatically increase in Lucija and in the territory of Sečovlje, which would cause particular difficulties to Airport of Portorož.

\section{Conclusion}

The damage caused by stronger floods is differing from year to year, but the altitude of the flood sea level approximately corresponds to the material damage caused by floods. The map of flood areas during extreme and yearly floods relatively well illustrates threats to the Slovenian coast. It would be necessary to monitor floods for several years and mapping the extensions of each particular flooding event on-site for making more precise maps of flood areas, which could be used for spatial planning.

A great number of inhabitants would be endangered particularly during extreme floods, which is troublesome in various aspects. Slovenian coast is quite attractive for new buildings, tourist and other similar activities - as demonstrated by quite high density of population and buildings. Local and other authorities, judging from existing building plans, do not sufficiently realize the dangers to the area. From this we can conclude that the damage in case of extreme floods would be much higher than it was in the past. The town most at risk is Piran, because of its position exposed to high tides and south-east-wind. A lot 
of buildings in the town are directly on the coast, which is relatively low. During extreme floods a great part of the old city, where almost one fifth of inhabitants live, would be flooded. Until now, the floods have caused the worst damage just in Piran.

Beside the points mentioned, there is a new threat - the rise of a sea level because of global warming. The scientists predict that it can rise for half a meter by the end of the century. That could dramatically change the extent of floods on the Slovenian coast. The flood area would become much wider and the floods more frequent because every tide just a few centimeters above average would cause flooding. As a result, quite a number of inhabitants would be in danger. The problem may become pretty serious and resolving it would become a task for the state. For now, this are only predictions, for which we do not know if they will come true and, if they will, to what extent. A reasonable approach would be to take the above mentioned statements into consideration and use them in the management of this area, taking action already at first signs of the problem. This way, we could be prepared with adequate plans by the time of its full occurrence.

\section{References}

Agregirani podatki o številu prebivalcev, Geografski inštitut Antona Melika ZRC SAZU, 2004. Ljubljana. Bernot, F. 1983: Vzroki in pogostost poplav ob slovenski obali. Naravne nesreče kot naša ogroženost. Ljubljana. Bernot, F. 1993a: Poplave ob slovenski obali. Ujma 7. Ljubljana.

Bernot, F. 1993b: Visoka plima ob slovenski obali 8. decembra 1992. Geografski vestnik 65. Ljubljana. Kunaver, J., Drobnjak, B., Klemenčič, M. M., Lovrenčak, F., Luževič, M., Pak, M., Senegačnik, J., Buser, S. 1996: Obča geografija. Ljubljana.

Morje je prestopilo bregove. Primorske novice, št. 53, 28. 12. 1979. Koper.

Mareographic station in Koper: Data from Mareographic station in Koper for the period 1963-2003. Koper. Plut, D. 1998: Varstvo geografskega okolja. Ljubljana.

Razdejana obala. Primorske novice, št. 46, 12.11.1966. Koper.

Robič, M. 2004: Visoke plime v letih 2002 in 2003. Ujma 17-18. Ljubljana.

Robič, M., Vrhovec, T. 2002: Poplavljanje morske obale. Naravne nesreče in varstvo pred njimi. Ljubljana. Titl, J. 1983: Območja morskih poplav v Koprskem Primorju. Naravne nesreče kot naša ogroženost. Ljubljana. Tudi slana poplava. Primorske novice, št. 83, 28. 12. 1980. Koper. 


\section{Ogroženost slovenske obale zaradi morskih poplav}

UDK: 556.166(497.4-14)

COBISS: 1.01

IZVLEČEK: Članek podaja pregled poplav morja na slovenski obali s poudarkom na njihovem nastanku, obsegu, ki ga lahko dosežejo, in posledicami. Poplave morja so med vsakoletnimi naravnimi nesrečami v Sloveniji, vendar se iz leta v leto njihova pogostost in obseg spreminjata. Prav tako se spreminja tudi materialna škoda, ki jo povzročijo. Vzrok za nastanek so predvsem visoka plima, močan južni veter in padanje zračnega pritiska. Pogostejše so jeseni in pozimi ter nekoliko manj tudi spomladi. $V$ članku so prikazani: pregled poplav od začetka meritev v Kopru, do današnjih dni, zemljevidi poplavnih območij in njihova analiza ter vpliv podnebnih sprememb.

KLJUČNE BESEDE: morje, poplave morja, poplavna območja, ogroženost, obala, Slovenija.

Uredništvo je prejelo prispevek 24. marca 2006.

NASLOV:

Nataša Kolega, univ. dipl. geogr.

Harpha sea, d. o. o. Koper

Čevljarska ulica 8, SI - 6000 Koper

E-pošta: natasa@harphasea.si

\section{Vsebina}

1 Uvod

2 Metode dela

3 Vzroki poplav

3.1 Dejavniki, ki vplivajo na nastanek močnejših plim $\quad 160$

3.1.1 Veter in valovanje

3.1.2 Zračni pritisk

3.1.3 Vremenske fronte

3.1.4 Reliefne oblike obale

3.2 Višina morja ob poplavah

$4 \quad$ Nekaj podatkov o močnejših poplavah morja med leti 1963 in 2003

4.1 Poplava in neurje od 3. do 5. novembra $1966 \quad 161$

4.2 Poplave 25. in 26. novembra 1969

4.3 Poplave v letih 1979, 1980 in 1982

$5 \quad$ Statistična obdelava podatkov o poplavah morja v letih 1963 do $2003 \quad 162$

$6 \quad$ Kartiranje poplavnih območij na slovenski obali 163

6.1 Površina poplavnega območja ob izjemnih in vsakoletnih poplavah morja 163

6.2 Opis poplavnih površin $\quad 164$

6.2.1 Ankaran 164

$\begin{array}{lll}6.2 .2 & \text { Koper } & 164\end{array}$

$\begin{array}{lll}6.2 .3 & \text { Izola } & 164\end{array}$

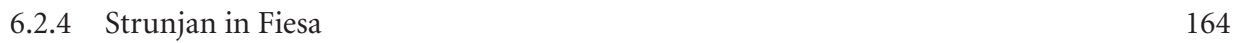

$\begin{array}{lll}6.2 .5 & \text { Piran } & 164\end{array}$

$\begin{array}{lll}6.2 .6 & \text { Portorož } & 165\end{array}$

$\begin{array}{lll}6.2 .7 & \text { Lucija } & 165\end{array}$

$\begin{array}{ll}\text { 6.2.8 Seča in Sečovlje } & 165\end{array}$

6.3 Število prebivalcev na ogroženih območjih $\quad 165$

6.4 Zazidalni načrti za poplavna območja 166

6.5 Vpliv globalnega segrevanja ozračja na poplave morja 166

6.5.1 Analiza zemljevida poplavnega območja ob morebitnem dvigu morske
gladine $(\mathrm{za} 50 \mathrm{~cm})$ zaradi globalnega segrevanja ozračja

$7 \quad$ Sklep $\quad 167$

$8 \quad$ Viri in literatura $\quad 167$ 


\section{Uvod}

Ena izmed naravnih nesreč, ki pogosto prizadenejo Slovenijo, so poplave morja. Njihova razsežnost in povzročena škoda ponavadi nista posebno veliki, vendar ob posameznih dogodkih vrednost materialne škode naraste.

Do poplav morja pride zaradi nadpovprečno visoke plime, ki jo povzročijo določeni meteorološki dejavniki v kombinaciji s hidrološkimi dejavniki. Poseben vpliv imajo predvsem močan južni veter in nizek zračni pritisk. Poplave morja so najpogostejše jesenski, najmanj pa spomladi.

Sistematično merjenje višine gladine morja se je pri nas začelo leta 1958, vendar pa so podatki na razpolago šele od leta 1963 dalje. Omogočajo podrobnejši pregled poplav in nastale škode ter statistično analizo podatkov. S kartiranjem, opazovanjem in uporabo prej omenjenih podatkov smo naredili tudi dva zemljevida poplavnih območij.

\section{Metode}

Osnovna teoretska metoda je bila pregled literature, ki jo sestavljajo predvsem članki o posameznih poplavah v preteklosti in izpis meritev mareografa na carinskem pomolu v Kopru med leti 1963 in 2003. Poleg literature smo uporabili še ustne vire nekaterih stanovalcev poplavnega območja.

Poplavna območja smo tudi kartirali. Pri tem smo si pomagali s starejšimi in manj natančnimi zemljevidi poplavnih območij, digitalnim modelom reliefa, opazovanjem in izjavami ljudi, ki se spominjajo obsega posameznih poplav.

Podlaga zemljevida poplavnega območja na slovenski obali ob izjemnih in vsakoletnih poplavah so digitalni ortofoti posnetki. Območja poplav smo določili s pomočjo več dejavnikov. Iz digitalnega modela reliefa Slovenije, ki je narejen na mreži 25 krat 25 metrov, smo izdelali poligone za območja z nadmorskimi višinami $0,0 \mathrm{~m}, 1 \mathrm{~m}$ in $2 \mathrm{~m}$. Poligone smo nato položili na digitalne ortofoto posnetke in tako doblili zaključena območja. Ker pa je digitalni model reliefa narejen na osnovi točk, ki so med seboj oddaljene 25 metrov, tako ni bilo mogoče določiti ožjih obalnih območij, kjer se nadmorska višina bistveno spremeni na kratko razdaljo. Tak primer je Piran, kjer se nadmorska višina zelo hitro spremeni od obalne ravnice do vrha flišnega klifa. Zato so na takšnih območjih poligonske datoteke iz digitalnega modela reliefa služile le kot opora za delo na terenu oziroma za orientacijo, dejansko poplavno območje pa smo določili z opazovanjem na terenu in pričevanji ljudi. Digitalni model reliefa ima še eno pomanjkljivost za določanje poplavnega območja. Vrednosti nadmorske višine so le cela števila, tako se na primer ne da omejiti območja z nadmorsko višino $30 \mathrm{~cm}$.

Podlaga zemljevida poplavnega območja ob morebitnem dvigu morske gladine za $50 \mathrm{~cm}$ je digitalni model reliefa, da je ponazoritev bolj plastična. Merilo zemljevida je manjše, kot pri zemljevidu poplavnega območja pri sedanjih višinah morja, saj gre le za predvidevanja. Zemljevid prikazuje poplavljena območja ob dvigu gladine morja za $50 \mathrm{~cm}$. Takšen dvig predvidevamo v 21 . stoletju zaradi segrevanja ozračja. Izdelan je s pomočjo zemljevida poplavnega območja ob izjemnih in vsakoletnih poplavah in digitalnega modela reliefa.

\section{Vzroki poplav}

Temeljni pogoj za poplave morja na slovenski obali je visoka plima, vendar nanjo vplivajo še drugi dejavniki, kot so veter, valovanje, zračni pritisk, gravitacijska privlačnost Lune oziroma tip plime, vremenske fronte in reliefna izoblikovanost obale. Višino plime in oseke ter čas njunega izmenjavanja lahko vnaprej natančno predvidimo, zato lahko ob upoštevanju prej naštetih dejavnikov predvidimo tudi poplave.

Plimovanje je izmenično dvigovanje in upadanje morske gladine, povzročeno s privlačno silo Lune in Sonca (Kunaver et al. 1996). Širi se v obliki dolgih valov, ki povzročajo periodično nihanje gladine. Njeno dvigovanje imenujemo plima, njeno upadanje pa oseka. Izmenjavata se na približno 6 ur do 6 ur in 30 minut.

Ko Luna potuje okoli Zemlje s svojo privlačno silo dobesedno spreminja obliko planeta. Ko Luna prekorači krajevni poldnevnik, kar imenujemo Lunina zgornja kulminacija, privlači vodne gmote in te se 
dvignejo. Hkrati se enako dogaja na nasprotni strani Zemlje, kjer nastopa Lunina spodnja kulminacija, le da je tam amplituda plimovanja nekoliko šibkejša. V času vzhajanja in zahajanja Lune se pojavi oseka, torej 90 stopinj vzhodno in zahodno od geografske dolžine, kjer nastopa plima, saj od tam privlačna sila Lune vodo "privleče« k sebi.

Na plimovanje vpliva tudi Sonce, ki je sicer od Zemlje zelo oddaljeno, vendar ima tako veliko maso, da je njegova privlačna sila tudi pomemben dejavnik pri plimovanju. Njegov vpliv je približno enak slabi polovici Luninega vpliva.

Plimovanje je najizrazitejše ob mlaju in ščipu, ko sta Sonce in Luna v konjunkciji oziroma opoziciji (Sonce, Luna in Zemlja so na ena premici) in se plimotvorni vplivi seštevajo. Ta položaj imenujemo sizigij, plimo pa sizigialna plima. Ob prvem in zadnjem krajcu, ko je Luna pravokotno na smer Zemlja-Sonce, je plimovanje najšibkejše, saj se vplivi odštevajo. To imenujemo obdobje kvadrature oziroma kvadraturna plima (Robič in Vrhovec 2002).

Amplituda plimovanja je po svetu zelo različna, od nekaj centimetrov do prek 20 metrov. Povprečna dnevna amplituda v Kopru znaša okrog 60 centimetrov in se ob vplivu drugih dejavnikov lahko zelo poveča. Razlika med najvišjo in najnižjo gladino morja je v Kopru v letih 1955-1997 znašala 286 centimetrov (Robič in Vrhovec 2002).

\subsection{Dejavniki, ki vplivajo na nastanek močnejših plim}

\subsubsection{Veter in valovanje}

Dviganje in zniževanje gladine sta zelo odvisna od smeri in jakosti vetra. Ob slovenski obali vetrovi s severnega kvadranta nižajo vodno gladino, saj vodo s severnega Jadrana odrivajo proti jugu. Tak veter je burja, ki piha s severovzhoda. Vetrovi z južnega kvadranta pa višajo gladino vode. Tak zelo pogost veter je jugo, ki piha z jugovzhodne smeri, enakomerno, brez sunkov in običajno kaže na poslabšanje vremena. Ker piha z južnega Jadrana proti severu, nariva vodo proti Tržaškemu zalivu in lahko povzroča velike valove. »... Porast vodne gladine zaradi zmernega in dolgotrajnega juga lahko znaša okoli $25 \mathrm{~cm}$, medtem ko se ob zelo močnem jugu, zlasti jeseni ali v prvi polovici zime, gladina morja lahko dvigne tudi preko pol metra... «(Bernot 1983, 50). Tako dvignjena gladina morja ob plimi pogosto poplavlja nižje ležeče dele obale.

Valovi so tudi posledica vetra in imajo pri poplavah morja zelo pomembno vlogo. Valovi juga so lahko visoki tudi nekaj metrov in s tem dajo poplavi še rušilno moč. Ob poplavah, ki jih spremljajo neurje $\mathrm{z}$ močnim vetrom in visoki valovi, so pogosto poškodovani ali uničeni objekti neposredno ob obali.

\subsubsection{Zračni pritisk}

Drugi atmosferski dejavnik, ki vpliva na zviševanje gladine morja, je zračni pritisk, ki je sicer povezan $\mathrm{Z}$ vetrom, vendar že spreminjanje zračnega pritiska samega po sebi povzroča spremembe $\mathrm{v}$ višini gladine morja. Znižanje zračnega pritiska za $1 \mathrm{mb}$ ustreza zvišanju gladine za $1 \mathrm{~cm}$ (Bernot 1993a) ali celo $1,5 \mathrm{~cm}$ (Robič 2004). Proces deluje tudi v drugo smer.

Ob slabem vremenu in jugu, za katerega je značilen nizek zračni pritisk, lahko le-ta pade tudi za več kot $20 \mathrm{mb}$ na dan, kar povzroči dvig morske gladine za $20 \mathrm{~cm}$. V času, ko morje poplavlja, zračni pritisk pogosto doseže vrednosti okoli $992 \mathrm{mb}$ (na primer oktobra 1982), kar je precej manj od dolgoletnega oktobrskega povprečja za Koper, ki znaša 117,7 mb (Bernot 1983).

\subsubsection{Vremenske fronte}

Vremenske fronte so s plimovanjem povezane posredno prek zračnega pritiska in vetra.

Tipična vremenska slika za dneve, ko morje na slovenski obali poplavlja, je sledeča: nad vzhodno ali severno Evropo je območje obsežnega anticiklona, nad Britanskim otočjem pa se zadržuje ciklon, ki določa vreme v zahodni Evropi. Anticiklon nad vzhodno Evropo začne slabeti in se pomikati proti vzhodu, ciklon iznad Britanskega otočja pa se še poglablja in premika proti srednji Evropi. Južno od Alp se v Genovskem zalivu oblikuje sekundarno jedro ciklona, ki se nato pomika proti vzhodu in zajame naše kraje. Pri tem na Jadranu pihajo močni južni vetrovi (Bernot 1983; 1993a; 1993b). 


\subsubsection{Reliefne oblike obale}

Slovenska obala sodi med obale riaškega tipa, za katere velja, da je glavna smer obale prečna na geološko zgradbo. Zanjo so značilni dolgi zalivi v potopljenih rečnih dolinah, med katerimi segajo daleč v morje višji polotoki. Poglavitne reliefne oblike so obalne ravnice v notranjosti zalivov in strmi klifi na obalah polotokov.

Na nihanje vodne gladine pa vpliva tudi lastno nihanje Jadranskega morja, ki se pojavi v zaprtih ali delno zaprtih bazenih in traja še po prenehanju delovanja sil, ki ga povzročajo. Perioda tega nihanja znaša približno 21 ur (Robič 2003/2004).

Pri reliefu velja omeniti še en dejavnik, ki plime ne povečuje, temveč se njuna vpliva združita in povzročata močnejše poplave z večjim poplavnim območjem. Ko se višina morja dvigne in se voda iz celotnega Jadrana nariva proti severu, to zajezi ustja rek, ki se tu izlivajo vanj. To povzroči, da rečna voda ne more odtekati in se zato dvigne višina rek, ki nato poplavijo določeno območje blizu izliva. Poplavni območji morja in rek se s tem združita.

\subsection{Višina morja ob poplavah}

Višino morske gladine lahko opišemo na dva načina. Določimo lahko višino nad ali pod srednjo obdobno vrednostjo. Srednji obdobni vrednosti pripišemo vrednost 0 . Plime označimo s predznakom plus (+), oseke s predznakom minus (-).

Določamo pa jo lahko tudi prek mareografske ničle (0) na mareografski postaji v Kopru. Pri tem načinu imajo vse vrednosti pozitiven predznak (oziroma predznaka sploh ni), saj srednji obdobni vrednosti 0 ustreza višina $215 \mathrm{~cm}$.

Morje na slovenski obali poplavi najnižje ležeče predele, ko gladina vode za $85 \mathrm{~cm}$ preseže srednjo obdobno vrednost oziroma je višina na vodomerni letvi z mareografsko ničlo $300 \mathrm{~cm}$ (Robič in Vrhovec 2002).

Povprečna vrednost plime med letoma 1958 in 1990 je znašala $248 \mathrm{~cm}$ na vodomerni letvi z mareografsko ničlo, oziroma $33 \mathrm{~cm}$ nad srednjo obdobno vrednostjo, povprečna vrednost oseke za isto obdobje pa $182 \mathrm{~cm}$ na vodomerni letvi ali $-33 \mathrm{~cm}$ pod srednjo obdobno vrednostjo. Povprečna amplituda v tem obdobju je torej znašala $66 \mathrm{~cm}$. Najvišja izmerjena gladina vode je bila leta $1969,394 \mathrm{~cm}$ ali $179 \mathrm{~cm}$ nad srednjo obdobno vrednostjo (Mareograf v Kopru 1969).

\section{Nekaj podatkov o močnejših poplavah morja med leti 1963 in 2003}

Med leti 1963 in 2003, ko so na razpolago podatki mareografa v Kopru, lahko izpostavimo nekaj močnejših poplav.

\subsection{Poplava in neurje od 3. do 5. novembra 1966}

Gladina vode je dosegla najvišjo višino 4. novembra ob 20 uri, to je kar $352 \mathrm{~cm}$ (Mareograf v Kopru 1966). Pri tem je bilo na Tartinijevem trgu v Piranu približno pol metra vode.

Neurje in visoka gladina morja sta povzročila precej škode, največ v Piranu, saj je tam največ objektov neposredno izpostavljenih morju. V Piranu je bilo razmajano in spodkopano obalno zidovje, razbita je bila Kavarna Tartini v stavbi gledališča (današnji Caffe Teater), poslovalnica avtobusne postaje, gostišče Riviera, ravno tako tudi kopališče ob dohodu v mesto, restavracija Hotela Piran in mnoge zasebne garaže ter avtomobili. Ves dan je bila zaprta cesta med Piranom in Lucijo, mnogo škode je bilo tudi drugod ob slovenski obali (Primorske novice 1966). Na plaži v Portorožu so bili uničeni leseni pomoli, razbita vrata kabin in odnesenih je bilo okrog 50 vagonov mivke, s sidrišč pa so bili odtrgani številni čolni (Titl 1983). 


\subsection{Poplave 25. in 26. novembra 1969}

Poplave 25. in 26. novembra 1969 so enakomerno zajele vso obalo. Voda je segala $94 \mathrm{~cm}$ v višino. Obalna cesta Koper-Sečovlje je bila na več mestih poplavljena, prav tako vsi cestni odseki proti Izoli, Portorožu in Piranu. Mnogo škode je neurje povzročilo na avtomobilih, parkiranih na Tartinijevem trgu v Piranu, saj jih je zalila morska voda skoraj do višine enega metra, nekatere pa so sunki vetra celo treščili ob zidove. V Kopru je morje zalilo poleg nižjih predelov mesta tudi večino Bonifike z osnovno šolo vred (Titl 1983).

To je bila najmočnejša poplava v preučevanem obdobju, povzročila je tudi največ materialne škode.

\subsection{Poplave v letih 1979, 1980 in 1982}

22. decembra 1979 je morje doseglo višino $356 \mathrm{~cm}$. Na tedanji Cesti JLA (današnje Fornače in Dantejeva ulica) je bilo do $60 \mathrm{~cm}$ vode, v Piranu pa je zalilo tudi Tartinijev trg z okolico. V Kopru je na križišču pri Slavniku morje mimo zaščitnih vreč udrlo na Bonifiko in jo zalilo. Zalilo je tudi prostore Splošne banke Koper (današnje Banke Koper) in tržnico (Primorske novice 1979).

25. oktobra 1980 je morje doseglo višino $361 \mathrm{~cm}$, kar je druga najmočnejša poplava v tem obdobju. Največ slane vode je bilo ponovno na tedanji Cesti JLA (današnje Fornače) v Piranu, na Ukmarjevem trgu v Kopru in na Semedelski cesti. Na parkirišču hotela Triglav v Kopru je bilo zalitih več avtomobilov. Večje škode tokrat ni bilo, saj plime ni spremljal močan jugo (Primorske novice 1980).

6. in 7. decembra 1982 je gladina morja ponovno dosegla višino $361 \mathrm{~cm}$. Poplava je najbolj prizadela Piran in obalno območje med Piranom in Sečoveljskimi solinami. V solinah so bili podrti nasipi, tako da so bile soline precej uničene. Veliko škode je bilo tudi v Droginem obratu Začimba v Seči, kjer so bili pod vodo proizvodni obrati. Na območju Izole in Kopra je škoda nastala samo na poplavljenih avtomobilih (Titl 1983).

\section{Statistična obdelava podatkov o poplavah morja v letih 1963 do 2003}

V enainštiridesetletnem obdobju je gladina morja 299-krat dosegla ali presegla točko poplavljanja $300 \mathrm{~cm}$. Povprečna višina morja, ob poplavljanju, je bila $309 \mathrm{~cm}$. Najvišja izmerjena višina morja v preučevanem obdobju je bila $394 \mathrm{~cm}$, kar je skrajnost, saj se sicer tako visoke vrednosti niso pojavljale. Povprečno je bilo 7,3 poplav na leto.

Letno število poplav se od leta do leta zelo razlikuje, prav tako pa se razlikujejo tudi najvišje letne vrednosti višine morja. Pojava nista zelo močno povezana, saj je bilo na primer v določenih letih zelo malo poplav in tudi višine morja so bile zelo nizke, spet $\mathrm{v}$ drugih letih pa so bile pri majhnem številu poplav dosežene visoke višine. Ravno tako pri velikem številu poplav ne moremo pričakovati visokih višin morja.

Če opazujemo samo višine, ki jih gladina morja ob poplavah dosega, lahko opazimo določen trend (slika 1). Nekaj let so višine relativno visoke, nakar sledi nekaj let z relativno nizkimi višinami, niz se nato ponovi. Iz slike 1 je mogoče razbrati tri obdobja, ko je morje dosegalo višje vrednosti in med njimi dve obdobji z nižjimi vrednostmi. Podoben trend je opazen tudi pri številu poplav na leto.

V zadnjem desetletju je opazno povečanje števila poplav med letom, vendar pa te poplave ne dosegajo posebno visokih vrednosti.

Slika 1: Najvišje višine gladine morja in število poplav na leto v letih 1963 in 2003.

Glej angleški del prispevka.

Iz podatkov o številu poplav na leto in najvišjimi višinami morja v enem letu, smo izračunali Pearsonovo korelacijo. Korelacija je zelo nizka 0,247, kar pomeni, da je pojasnjena varianca 0,061 oziroma, da lahko le približno $6 \%$ najvišjih višin morja pojasnimo s številom poplav. To je posledica dejstva, da s Pearsonovim koeficientom računamo le linerane korelacije. Če »z vrednosti« podatkov interpoliramo s polinomom šestega reda lahko vidimo, da so pojavi korelirani. Iz slike 2 je razvidno, da so si krivulje med seboj podobne. Za potrditev tega smo izračunali korelacijo predznakov odvoda, ki nam pove v koliko primerih krivulji skupaj naraščata ali padata, ne pa za koliko narašča ali padata. Opazili smo, da povezanost obstaja pri $90 \%$ vrednosti. Sklepamo lahko, da zveza med pojavoma obstaja, vendar je s Pearsonovo korelacijo ne moremo pojasniti. 
Na podlagi tega smo poskusili ekstrapolirati podatke iz katerih smo izločili robne vrednosti, ki pretirano odstopajo (vredosti pred letom 1966 in po letu 1990). Če izračunamo Pearsonov koeficient zgolj na teh podatkih, je rezultat vrednost 0,551 , kar pomeni da je pojasnjena varianca 0,301 oziroma, da lahko približno $30 \%$ najvišjih višin pojasnimo s številom poplav. Ker sta vzorec in statistična pomembnost zelo majhna, tako visoka pojasnjena varjanca pomeni, da lahko povezanost med najvišjimi višinami in številom poplav med letoma 1966 in 1990 le slutimo.

Slika 4 prikazuje število poplav po mesecih. Poplave so zelo značilne za jesensko-zimsko obdobje od oktobra do januarja, največ poplav je novemrba. Poplave so pogoste tudi spomladi, zelo redke pa so poleti. Vzrok za takšno razporeditev je zlasti večja pogostost genovskega ciklona v hladnem delu leta.

Slika 2: »Z vrednosti« najvišjih višin morja in »Z vrednosti« števila poplav na leto.

Glej angleški del prispevka.

Slika 3: Število poplav po mesecih med leti 1963 in 2003.

Glej angleški del prispevka.

\section{Kartiranje poplavnih območij na slovenski obali}

\subsection{Površina poplavnega območja ob izjemnih in vsakoletnih poplavah morja}

Za izjemne poplave so štete poplave, ki dosegajo ali presegajo višino $394 \mathrm{~cm}$, kar je najvišja vrednost, ki jo je višina gladine morja dosegla v obdobju od leta 1963 do leta 2003. Za omenjeno poplavo, ki se je zgodila 26. novembra 1969, je leta 1983 narisal okvirne zemljevide poplavnih območji že Julij Titl (Titl 1983). Zemljevide smo uporabili za natančnejše določanje poplavnega območja. Višina vode $394 \mathrm{~cm}$ skoraj ustreza vrednosti $2 \mathrm{~m}$ nadmorske višine na digitalnem modelu reliefa. Geodetska kota 0 je namreč enaka vrednosti $200 \mathrm{~cm}$, ki je v digitalnem modelu reliefa označena kot 0 metrov. Iz tega sledi, da vrednosti $1 \mathrm{~m}$ na digitalnem modelu reliefa ustreza $300 \mathrm{~cm}$. Vrednost $2 \mathrm{~m}$ na digitalnem modelu reliefa pa ustreza vrednosti $400 \mathrm{~cm}$ - to pa je le $6 \mathrm{~cm}$ višje od najvišje izmerjene vrednosti $394 \mathrm{~cm}$.

Razsežnosti te poplave se dobro spominja kar nekaj ljudi, predvsem na območju Pirana, zato smo pri izdelavi zemljevida upoštevali tudi njihovo pričevanje.

Drugi podatek, ki ga zemljevid prikazuje, je poplavno območje ob pogostejših, vsakoletnih poplavah pri vrednosti $330 \mathrm{~cm}$ ali $30 \mathrm{~cm}$ nad točko poplavljanja. Pri omejevanju tega poplavnega območja smo uporabili lastno opazovanje reliefa pa tudi večkratno opazovanje poplav takih razsežnosti v preteklih letih.

Poplavno območje je najobsežnejše v občini Piran, zlasti zaradi največje poplavne površine - Sečoveljskih solin. Najmanj obsežno je poplavno območje v občini Izola. Poplavno območje vsakoletnih poplav pokriva $26,85 \%$ poplavnega območja ob izjemnih poplavah.

Preglednica 1: Površina poplavnih območij ob izjemnih in vsakoletnih poplavah morja.

\begin{tabular}{lc}
\hline poplavno območje & površina v km² \\
\hline poplavno območje ob izjemnih poplavah & \\
\hline mestna občina Koper & 6,12 \\
občina Izola & 0,20 \\
občina Piran & 7,71 \\
ve tri občine skupaj & 14,04 \\
\hline poplavno območje ob vsakoletnih poplavah & \\
\hline mestna občina Koper & 0,25 \\
občina Izola & 0,03 \\
občina Piran & 3,48 \\
ve tri občine skupaj & 3,77 \\
\hline
\end{tabular}

Slika 4: Poplavno območje, na slovenski obali, ob izjemnih in vsakoletnih poplavah.

Glej angleški del prispevka.

Slika 5: Izsek iz zemljevida poplavnega območja, na slovenski obali, ob izjemnih in vsakoletnih poplavah, ki prikazuje Piran z okolico.

Glej angleški del prispevka. 


\subsection{Opis poplavnih površin}

\subsubsection{Ankaran}

Na območju Ankarana je več med seboj ločenih poplavnih površin različnega obsega. Ob izjemnih poplavah bi bilo poplavljeno območje ob mejnem prehodu Lazaret in bencinski črpalki, kjer razen omenjenih objektov, ni drugih zgradb. Ob vsakoletnih poplavah je poplavljen le ožji del neposredno ob obali.

Približno $500 \mathrm{~m}$ zahodno od mejnega prehoda je kopališče z nekaj zgradbami, ki bi bile ob izjemnih poplavah pod vodo. Prav tako bi bila pod vodo kopališča pred Mladinskim zdraviliščem in tako imenovano kopališče »Gradis«, vendar tu ni stavb, ki bi bile ogrožene. Sledi kopališče pod Ortopedsko bolnišnico Valdoltra, kjer je površje nižje, zato bi bil od tu dalje poplavljen celoten obmorski pas do Luke Koper. V tem pasu je več odsekov, kjer bi izjemne poplave lahko povzročile večjo škodo. Najbolj problematičen je avtokamp Adria, ki bi bil ob izjemnih poplavah z vsemi objekti skoraj do polovice poplavljen. Pri Sveti Katarini, bi bilo ob izjemnih poplavah poplavljeno manjše pristanišče in nekaj okoliških objektov. Vsakoletne poplave na območju Ankarana ne povzročajo bistvenih težav in škode.

\subsubsection{Koper}

V Kopru in v njegovi okolici je, zlasti ob izjemnih poplavah, kar nekaj poplavnih površin. Luka Koper, bi bila zaradi svoje lege ob izjemnih poplavah skoraj v celoti zalita. To bi utegnilo povzročiti kar nekaj gmotne škode. Voda bi se razlivala skoraj do Srmina.

Ob vsakoletnih poplavah so zaliti le nižji deli Luke Koper, kar ne povzroča posebnih težav.

Ob izjemnih poplavah bi bila potopljena tudi koprska Bonifika in del Olma ter Šalare ob Badaševici, kjer je obsežno poseljeno območje. V starem delu Kopra bi bila ob močnih poplavah zalita Marina Koper, Ukmarjev trg, del Carpacciovega trga in okolica, Pristaniška ulica, Ljubljanska ulica ter Bonifika. V starem mestnem jedru bi bilo zalitih kar nekaj hiš.

Ob vsakoletnih poplavah so zaliti Semedelska cesta, del Marine Koper in obala v neposredni okolici koprskega pristanišča. Stanovanjske stavbe niso ogrožene.

Ob izjemnih poplavah bi bilo zalito tudi območje proti Žusterni s parkiriščem in kopališčem vred ter magistralna cesta med Koprom in Izolo, ob vsakoletnih poplavah pa le kopališče.

\subsubsection{Izola}

Na območju Izole bi bil ob izjemnih poplavah poplavljen skoraj celoten avtokamp Jadranka, ob vsakoletnih poplavah pa le njegov nižji del, neposredno ob obali.

Ob močnih poplavah bi bil poplavljen tudi velik del Ladjedelnice Izola, kar bi pomenilo precejšnjo gmotno škodo na objektih. Poplavljeni bi bili tudi kopališče zahodno od Ladjedelnice Izola in rtič, kjer je svetilnik.

Poplavljen bi bil velik del mesta Izola: ob pristanišču, Veliki trg, Manziolijev trg ter vse do Ljubljanske ulice ter Gorkijeve ulice. Poplavljena bi bila tudi Marina Izola s pripadajočimi objekti, območje do Simonovega zaliva in precej stanovanjskih objektov, zlasti v starem mestnem jedru.

Ob vsakoletnih poplavah je poplavljena le obala neposredno ob morju in redki stanovanjski objekti na Velikem trgu in morda ob marini.

\subsubsection{Strunjan in Fiesa}

V Strunjanu je ob vsakoletnih poplavah poplavljeno kopališče in soline, ob izjemnih poplavah pa bi bilo poplavljeno tudi območje ob Strunjanskem potoku oziroma okolica strunjanskega križišča. Tu bi bilo prizadetih tudi nekaj hiš.

Poleg tega morje, zlasti ob izjemnih poplavah, poplavlja tudi plažo pred turističnim kompleksom Salinera.

V Fjesi običajno poplavlja kopališče, ob izjemnih poplavah pa tudi travnik med kopališčem in fješkim jezerom. Zgradbe niso ogrožene.

\subsubsection{Piran}

Piran poplave najbolj ogrožajo. Tudi v preteklosti so prav poplave v Piranu povzročale največjo škodo. Ob izjemnih poplavah bi bil poplavljen velik del starega mestnega jedra. Voda bi se razlivala po celotni 
obali okrog rta Madona do Resslove ulice in začetka Gregorčičeve ulice (za nekdanjim hotelom Punta) ter nato do spodnje polovice Trga 1. maja in Verdijeve ulice. Zalit bi bil tudi celoten Tartinijev trg, nato pa območje do ulice Svobode in Tomšičeve ulice. Poplavljena bi bila tudi Dantejeva ulica in celotne Fornače. Poplavljenih bi bilo veliko hiš, gmotna škoda bi bila razmeroma visoka.

Ob vsakoletnih poplavah so poplavljeni Kidričevo in Prešernovo nabrežje, Tartinijev trg in del Cankarjevega nabrežja s pristaniščem, $\mathrm{v}$ smeri proti izhodu iz mesta pa le najožji del obale. Za razliko od večine drugih krajev, je v Piranu tudi ob vsakoletnih poplavah poplavljenih nekaj hiš ob Prešernovem in Kidričevem nabrě̌ju.

\subsubsection{Portorož}

Na Bernardinu bi bilo zlasti ob izjemnih poplavah poplavljeno kopališče pred Grand hotelom Bernardin ter kopališče in manjše pristanišče ob hotelu Histrion. Zaliti bi bili tudi glavna bernardinska plaža in prostori jadralnega kluba Pirat, kjer bi bila ob močnejših poplavah zalita tudi čolnarna Fakultete za pomorstvo in promet. Poplavljena bi bila tudi tako imenovana »Študentska plaža«, ob močnih poplavah pa tudi obala pred skladišči soli.

V samem Portorožu bi bile poplavljene predvsem plaže pred hotelom Riviera in glavna portoroška plaža, poleg njiju pa tudi pristaniški pomol in obala med omenjenima plažama.

Objekti v Portorožu so večinoma nekoliko dvignjeni nad morsko gladino, zato tudi ob močnih poplavah ne bi bili poplavljeni.

\subsubsection{Lucija}

Ob izjemnih poplavah bi bil v Luciji zalit kar precejšen del površja. Zalita bi bila skoraj celotna Marina Portorož, voda pa bi se prelivala še naprej proti progi za gokart in zdravstvenem domu. Zalilo bi tudi del Obale in Ukmarjeve ulice. Ob potoku Fazan bi se voda prelivala še naprej vse do Fazana in Fazanske ulice. $\mathrm{V}$ primeru tako močnih poplav bi bilo zalitih veliko stanovanjskih in drugih objektov, kar bi lahko povzročilo znatno škodo.

Ob vsakoletnih in ob izjemnih poplavah je zalita tudi lucijska plaža, pa tudi ožji del obale ob kanalu na izlivu potoka Fazan, ki služi kot pristanišče za manjše čolne.

Zlasti ob izjemnih poplavah bi zalilo plažo avtokampa Lucija, njegovih površin pa ne, saj so le te nekoliko dvignjene oziroma le deloma v bližini morja.

Vsakoletne poplave v Luciji ne povzročajo posebnih problemov oziroma škode, saj voda zalije le ožje obalne predele in kopališča.

\subsubsection{Seča in Sečovlje}

V Seči in Sečovljah je največja poplavna površina na slovenski obali. To so Sečoveljske soline, ki so v večjem delu poplavljene že ob vsakoletnih poplavah, ob izjemnih pa bi bile v celoti pod vodo. Voda bi se razlivala tudi po dolini navzgor in zaradi zajezitve Drnice z visoko plimo bi bili poplavljeni tudi del naselja Sečovlje, obdelovalne površine v njegovi okolici ter del Letališča Portorož. Poplavljenih bi bilo tudi nekaj stanovanjskih objektov.

Ob izjemnih poplavah lahko morje zalije nekdanji obrat Začimba Droge Portorož pri kanalu sv. Jerneja v Seči, kar bi lahko povzročilo precejšnjo gmotno škodo.

Že ob vsakoletnih poplavah je zalita skoraj celotna cesta ob kanalu Svetega Jerneja, ob izjemnih poplavah pa bi bili zaliti še nekateri dodatni predeli, kot je manjša ladjedelnica in parkirišče pred gostilno Ribič. $\mathrm{Na}$ tem območju je večina stanovanjskih objektov zaradi reliefa nekoliko dvignjena, in ni nevarnosti, da bi jih zalilo.

\section{3 Število prebivalcev na ogroženih območjih}

Na poplavnih območjih, živi veliko prebivalcev. Ob vsakoletnih poplavah je ogroženih 22 ljudi v Piranu. V ostalih krajih vsakoletne poplave ne ogrožajo stanovanjskih objektov.

V treh obmorskih občinah živi 78.846 prebivalcev, v občini Koper 47.539, v občini Izola 14.549 in v občini Piran 16.758 (Popis 2002). 
Ob izjemnih poplavah bi bilo v vseh treh občinah ogroženih 2007 ljudi, največ v občini Piran (1262), 427 v občini Koper in 318 v občini Izola. Ogroženega je kar 2,54 \% prebivalstva vseh treh občin, v občini Piran pa kar 7,53\% prebivalcev občine oziroma 18,75\% prebivalcev Pirana.

Iz zgornjih podatkov lahko sklepamo, da bi ob nastopu izjemnih poplav zaradi precejšnjega števila ogroženega prebivalstva lahko nastale resne težave pri oskrbi, prometu, bivanju in ostalih dejavnostih, zlasti v Piranu.

\subsection{Zazidalni načrti za poplavna območja}

Med največjimi ali najbolj odmevnimi zazidalnimi načrti na poplavnih območjih izstopajo v Kopru izgradnja nove osnovne šole, gasilskega doma in zdravstvenega doma na Bonifiki, Gospodarske cone Sermin in 3. pomola Luke Koper.

V Izoli nameravajo graditi turistično-poslovno-stanovanjski kompleks Argolina, na širšem območju Simonovega zaliva pa večji turistični kompleks.

V Piranu je predvidena širitev vzletno-pristajalne steze Letališča Portorož, gradnja golf igrišča v Sečovljah ter obsežen ureditveni načrt za območje polotoka Seča, ki se dotika tudi robnih predelov solin oziroma celotnega predela ob kanalu svetega Jerneja, kjer morje pogosto poplavlja. Zgraditi nameravajo tudi novo marino, več vil in hotelov ter drugih objektov.

Naštetih je le nekaj največjih načrtov, poleg teh pa obstaja še množica manjših, od katerih so posamezni lahko še bolj izpostavljeni poplavam morja.

\subsection{Vpliv globalnega segrevanja ozračja na poplave morja}

Znanstveniki napovedujejo, da bo eden od najpomembnejših vplivov globalnega segrevanja porast morske gladine. Dvig morske gladine je posledica toplotnega širjenja morske vode, taljenja gorskih ledenikov in taljenja ledenikov na zemeljskih polih. Glede na današnjo višino gladine morja naj bi se le-ta do leta 2050 dvignila za približno $22 \mathrm{~cm}$, do leta 2100 pa za približno $50 \mathrm{~cm}$ (Plut 1998).

Izdelali smo zemljevid, ki prikazuje poplavna območja ob morebitnem dvigu morske gladine zaradi globalnega segrevanja. Predpostavili smo dvig morske gladine za $50 \mathrm{~cm}$. Če bi bila srednja višina gladine morja v prihodnosti za $0,5 \mathrm{~m}$ višja, bi že vsaka malo močnejša plima povzročila poplavo. Če sedanji vrednosti povprečne plime prištejemo $50 \mathrm{~cm}$, dobimo $298 \mathrm{~cm}$, kar pa je zelo blizu točki poplavljanja. Glede na to, da so plime različno visoke in da je njihova povprečna višina $33 \mathrm{~cm}$, lahko sklepamo, da bo do poplav prihajalo redno, tudi večkrat na mesec. Povprečna višina poplave, izračunana iz sedanjih vrednosti, bi bila za današnje razmere skoraj izjemna poplava $-359 \mathrm{~cm}$. Ob izjemnih poplavah pa bi bilo ob predpostavljenem scenariju na najnižje ležečih delih obale skoraj $1,5 \mathrm{~m}$ morske vode $(444 \mathrm{~cm})$.

Preglednica 2: Izračun višin morja za napovedani dvig gladine za $50 \mathrm{~cm}$.

\begin{tabular}{lcc}
\hline & $\begin{array}{c}\text { vrednost višine gladine } \\
\text { morja danes v cm }\end{array}$ & $\begin{array}{c}\text { vrednost višine gladine morja } \\
\text { pri dvigu gladine za } 50 \mathrm{~cm}, \mathrm{vcm}\end{array}$ \\
\hline srednja višina gladine morja & 215 & 265 \\
začetek poplavljanja & 300 & 300 \\
vrednost povprečne plime 1963-2003 & 248 & 298 \\
vrednost povprečne 0seke 1963-2003 & 182 & 232 \\
izjemna vrednost 1963-2003 & 394 & 444 \\
povprečna poplava 1963-2003 & 309 & 359 \\
vsakoletna poplava 1963-2003 & 330 & 380 \\
\hline
\end{tabular}

Slika 6: Poplavno območje ob morebitnem dvigu morske gladine $(\mathrm{za} 50 \mathrm{~cm})$ zaradi globalnega segrevanja ozračja.

Glej angleški del prispevka.

\subsubsection{Analiza zemljevida poplavnega območja ob morebitnem dvigu morske gladine (za $50 \mathrm{~cm})$ zaradi globalnega segrevanja ozračja}

Del ozemlja, ki bi bil ob dvigu gladine morja za $50 \mathrm{~cm}$ poplavljen ob vsakoletnih poplavah, bi lahko primerjali z delom ozemlja, ki je sedaj poplavljen pri izjemnih poplavah. Le-ta obsega približno $14 \mathrm{~km}^{2}$ oziroma 
dobre tri odstotke površine vseh treh obalnih občin. Vendar bi bile poplavne površine, ob porastu višine morja za $50 \mathrm{~cm}$, najverjetneje nekoliko manj obsežne, saj bi bila višina morja v primeru vsakoletnih poplav ob dvigu za $50 \mathrm{~cm}$ za $14 \mathrm{~cm}$ nižja kot je sedaj ob izjemnih poplavah (preglednica 2). Podobna primerjava je možna tudi za število ogroženih prebivalcev. Sklepamo lahko, da bi bilo ob porastu gladine za $50 \mathrm{~cm}$ pri vsakoletnih poplavah ogroženih več kot tisoč ljudi.

Največje poplavne površine bi nastale na območju koprske in ankaranske Bonifike, kar pomeni, da bi imela Luka Koper velike težave pri izvajanju svoje dejavnosti. Poplavne površine bi se bistveno povečale tudi v Izoli. Večje bi bile poplavne površine tudi v Strunjanu in Piranu, bistveno pa bi se povečale v Luciji, prav tako pa bi se poplavno območje precej povečalo na območju Sečovelj, kar bi lahko predstavljalo posebne probleme za Letališče Portorož.

\section{Sklep}

Škoda, ki jo lahko povzročijo večje poplave, se iz leta v leto spreminja, vendar se višina vode ob poplavah približno ujema $\mathrm{z}$ nastalo gmotno škodo.

Zemljevid poplavnih območji ob izjemnih in vsakoletnih poplavah razmeroma dobro ilustrira ogroženost tega območja. Da bi prišli do bolj natančnih zemljevidov, ki bi bili uporabni pri načrtovanju, bi morali več let spremljati poplave in ob vsakemu dogodku posebej iti na teren ter kartirati njene razsežnosti.

Zlasti ob izjemnih poplavah bi bilo ogroženo tudi precej veliko število prebivalcev treh obalnih občin, kar pa je zelo zaskrbljujoče iz več razlogov. Slovenska obala sodi med bolj privlačna območja za pozidave in turistične ter druge dejavnosti, kar dokazujejo precej velika gostota poselitve in pozidanost delov obmorskega pasu ter visoke cene zemljišč. Če sklepamo po obstoječih zazidalnih načrtih, se krajevne in druge oblasti, premalo zavedajo ogroženosti območja. Sklepamo lahko, da bi bila škoda ob izjemnih poplavah še veliko večja, kot je bila v preteklosti.

Najbolj ogroženo območje je mesto Piran, ki je zaradi lege izpostavljeno visokim plimam in južnemu vetru. Mesto je zasnovano tako, da je veliko hiš neposredno na obali, ki pa je relativno nizka. Ob izjemnih poplavah bi bil v Piranu tako zalit večji del starega mestnega jedra, kjer živi skoraj petina njegovega prebivalstva. Do sedaj so poplave povzročale največ škode prav v Piranu.

Poleg vsega naštetega nam grozi še nova nevarnost - dvig gladine morja kot posledica globalnega segrevanja ozračja. Znanstveniki napovedujejo, da se le-ta lahko do konca tega stoletja dvigne za pol metra, kar bi razsežnost poplav morja bistveno spremenilo. Poplavno območje bi bilo precej večje, poplave veliko pogostejše, saj bi poplavljala že vsaka, za nekaj centimetrov nadpovprečna plima. Ogroženo bi bilo tudi precej prebivalstva. Problem bi postal dokaj velik in z reševanjem bi se po vsej verjetnosti morala spopasti država. To so zaenkrat le napovedi, za katere natančno ne vemo, če se bodo uresničile in v kolikšni meri. Smiselno pa bi bilo zgornja spoznanja vnesti v upravljanje s prostorom območju in ukrepati že ob prvih pojavih problema, da bi bili ob njegovem polnem nastopu ustrezni načrti že pripravljeni.

\section{Viri in literatura}

Glej angleški del prispevka. 